\title{
Cartilage Oligomeric Matrix Protein Levels in Synovial Fluid in Patients With Primary Knee Osteoarthritis and Healthy Controls: A Preliminary Comparative Analysis With Serum Cartilage Oligomeric Matrix Protein
}

\author{
Ruben Daniel ARELlANO, ${ }^{1}$ Lizette Sarai AGUILAR, ${ }^{2}$ Rafael ARGÜELLO,${ }^{2}$ Fernando HERNADEZ, ${ }^{2}$ \\ Faviel Francisco GONZALEZ, ${ }^{3}$ Javier MORAN ${ }^{2}$ \\ ${ }^{1}$ Department of Orthopaedics, Autonomous University of Coahuila, Torreon, Mexico \\ ${ }^{2}$ Department of Molecular Biology, Autonomous University of Coahuila, Torreon, Mexico \\ ${ }^{3}$ Department of Bioinformatics, Autonomous University of Coahuila, Torreon, Mexico
}

\begin{abstract}
Objectives: This study aims (i) to compare synovial fluid and serum cartilage oligomeric matrix protein levels in patients with primary knee osteoarthritis and healthy controls, (ii) compare variations of synovial fluid and serum cartilage oligomeric matrix protein levels according to sex, Kellgren-Lawrence grades, and daytime sampling, and (iii) correlate the synovial fluid and serum cartilage oligomeric matrix protein levels with age, severity of disease, and daytime sampling.

Patients and methods: One hundred and twenty-four participants (44 males, 80 females; median age 66 years; range 42 to 87 years) were diagnosed with primary knee osteoarthritis according to the American College of Rheumatology guidelines. Additionally, 105 healthy individuals (49 males, 56 females; median age 50 years; range 30 to 75 years) were included as the control group. For both groups, a thorough clinical history and physical examination were performed. Moreover, weight-bearing anteroposterior and lateral bending 30 degrees knee X-rays were collected. Cartilage oligomeric matrix protein in serum and synovial fluid was measured by enzyme-linked immunosorbent assay.

Results: Total synovial fluid cartilage oligomeric matrix protein levels were considerably higher than total serum levels for both groups. Levels of cartilage oligomeric matrix protein in synovial fluid and serum were higher in patients than in controls for both sexes. However, only cartilage oligomeric matrix protein levels in synovial fluid were higher in female patients. The levels of synovial fluid cartilage oligomeric matrix protein were significantly higher when sampling after $12 \mathrm{pm}$. A positive correlation was found between synovial fluid and serum cartilage oligomeric matrix protein levels, age, and daytime sampling.

Conclusion: These findings may suggest a possible role for synovial fluid and serum cartilage oligomeric matrix protein as a measure for primary knee osteoarthritis. However, more studies need to be performed to address other factors that may influence the levels of cartilage oligomeric matrix protein in synovial fluid and serum.

Keywords: Cartilage oligomeric matrix protein; knee; osteoarthritis; synovial fluid.
\end{abstract}

Osteoarthritis (OA) is a common chronic degenerative and disabling disease caused by the interaction of multiple risk factors such as obesity, trauma, and hormonal and occupational factors. ${ }^{1}$ Chronic and symptomatic knee osteoarthritis (KOA) is believed to affect around 9.3 million young adults ( $\geq 45$ years) in the United States with an obvious economic burden and impact on quality of life. ${ }^{2}$ In Mexico, the prevalence of OA is estimated at $14 \%$ and it has been considered as the fourth cause of morbidity in adults over 60 years of age. ${ }^{3}$

Knee osteoarthritis involves cartilage degradation, joint space narrowing, osteophyte formation at the joint margins, and subchondral changes. At present, clinical history and X-rays

Received: September 23, 2016 Accepted: December 27, 2016 Published online: April 04, 2017

Correspondence: Ruben Daniel Arellano, MD. Department of Orthopaedics, Autonomous University of Coahuila, 27000 Torreon, Mexico.

Tel: 8717470526 e-mail: arellanodaniel1969@gmail.com

○2017 Turkish League Against Rheumatism. All rights reserved. 
are still the most reliable methods to diagnose and establish the severity of disease. As OA initiates before the radiographic alterations can be identified, the diagnosis is usually established at a very late stage of the disease. ${ }^{4,5}$ Hence, it is important to examine potential biochemical parameters not only to discriminate between $\mathrm{KOA}$ and its severity, but also to evaluate changes in markers concentrations and their relationship with other variables such as age, sex, and daytime variations, among others. ${ }^{6}$

Cartilage oligomeric matrix protein (COMP) is a $524-\mathrm{kDa}$ noncollagenous homopentameric protein present in cartilage., ${ }^{7,8}$ Although the function of COMP remains unclear, it has been suggested that this may have a role in endochondral ossification, interacting with collagen fibrils via each C-terminal globule, for extracellular matrix stabilization. It is also known for influencing fibril formation for collagens type I and II, accelerating fibrillogenesis and binding to aggrecan, mediating the organization of cartilage matrix for its load bearing function. ${ }^{9,10}$ In previous studies, serum COMP has been associated with diagnosis and prognosis of clinical KOA; ${ }^{11-14}$ however, it remains unclear whether COMP is sensitive enough to evaluate KOA patients.

While serum and urine sampling are easy to obtain, levels of biomarkers from both anatomical sides exhibit large interindividual variations, leading to the requirement of highly sensitive techniques to avoid such variations. Serum and urine levels of COMP may be influenced not only by metabolism and clearance, but also by other factors such as non-joint tissues, age, sex, or daytime variation. Thus, the specificity of this marker for KOA may be diminished, limiting its use in the assessment of patients. To clear this issue, synovial fluid (SF) markers may be more informative than systemic markers as they relate to structural changes and damage within a joint. Therefore, SF markers may be useful as diagnostic and prognostic tools, and to measure efficacy of intervention. ${ }^{15}$

A limited number of studies have been found in the literature related to the analysis of COMP levels in SF and/or comparing levels of COMP between SF with serum. ${ }^{16-18}$ In those studies, a high level of COMP was detected in both fluids, showing higher concentrations in SF than in serum indicating preferential release from the affected joints (Table 1).

In this study, we aimed (i) to compare SF and serum COMP levels in patients with primary $\mathrm{KOA}$ and healthy controls, (ii) compare variations of SF and serum COMP levels according to sex, Kellgren-Lawrence grades, and daytime sampling, and (iii) correlate the SF and serum COMP

Table 1. Previous studies on synovial fluid cartilage oligomeric matrix protein

\begin{tabular}{|c|c|c|c|c|c|}
\hline Author & Year & Disease & Participants & Sample & Reference \\
\hline Saxne and Heinegård ${ }^{16}$ & 1992 & $\begin{array}{l}\text { RA, OA, reactive arthritis, } \\
\text { juvenile chronic arthritis }\end{array}$ & 155 & $\mathrm{SF} /$ serum & Br J Rheumatol 1992;31:583-91 \\
\hline Lohmander et al. ${ }^{29}$ & 1994 & $\begin{array}{c}\text { KOA, knee injury, healthy } \\
\text { volunteers }\end{array}$ & 353 & SF & Ann Rheum Dis $1994 ; 53: 8-13$ \\
\hline Petersson et al. ${ }^{30}$ & 1997 & $\begin{array}{l}\text { KOA grade I, knee pain, } \\
\text { controls }\end{array}$ & $45 / 45 / 8$ & SF & Ann Rheum Dis $1997 ; 56: 64-7$ \\
\hline Neidhart et al. ${ }^{17}$ & 1997 & Cadaveric, KOA, RA, controls & 209 & $\mathrm{SF} /$ serum & Br J Rheumatol 1997;36:1151-60 \\
\hline Kühne et al. ${ }^{31}$ & 1998 & Knee trauma & 30 & SF/serum & Rheumatol Int 1998 \\
\hline El-Arman et al. ${ }^{21}$ & 2010 & $\begin{array}{c}\mathrm{KOA} \text {, knee trauma as } \\
\text { controls }\end{array}$ & $66 / 20$ & $\mathrm{SF} /$ serum & HSSJ 2010;6:171-6 \\
\hline Åhrman et al. ${ }^{18}$ & 2014 & $\begin{array}{c}\text { Acute trauma, knee pain, } \\
\text { OA, RA }\end{array}$ & 75 & SF & J Biol Chem 2014;289:20908-16 \\
\hline Gheita, et al. ${ }^{22}$ & 2015 & $\mathrm{KOA}$ & 23 & $\mathrm{SF} /$ serum & $\begin{array}{c}\text { Abstracts/Osteoarthritis } \\
\text { Cartilage 2015;23:A85 }\end{array}$ \\
\hline
\end{tabular}


levels with age, severity of disease, and daytime sampling.

\section{PATIENTS AND METHODS}

Two hundred and twenty-nine participants (93 males, 136 females; mean age 59 years; range 30 to 87 years) were recruited between March 2015 and May 2016 from Hospital General ISSSTE in Torreon, Mexico. One hundred and twenty-four participants (44 males, 80 females; median age 66 years; range 42 to 87 years) were diagnosed with primary KOA according to the American College of Rheumatology guidelines. Disease severity was classified using the KellgrenLawrence criteria (grade II, mild; grade III, moderate; grade IV, severe). Patients were males and non-pregnant females above 40 years of age with recent diagnosis of primary KOA. All patients with secondary arthritis of knee joint, rheumatic, inflammatory or septic joint disease, treatment for osteoarthritis, renal, hepatic or malignant disease, participating in any athletic or heavy working activity, or SF contamination with blood or pus were excluded. Additionally, 105 healthy individuals (49 males, 56 females; median age 50 years; range 30 to 75 years) were included as control group. Controls were males and non-pregnant females above 40 years of age with no evidence of any articular disease. For both groups, a thorough clinical history and physical examination were performed. Moreover, weight-bearing anteroposterior and lateral bending 30 degrees knee X-rays were collected.

Of the total 229 participants, 77 samples corresponded to SF only, 78 samples to serum only, and for 74 individuals, both SF and serum samples were taken. The study protocol was approved by the Clinica del Magisterio Ethics Committee. All patients provided written informed consent. The study was conducted in accordance with the principles of the Declaration of Helsinki.

For the patient group, knee joint aspiration was carried out under aseptic conditions for therapeutic reasons. Knee aspiration for the controls was also carried out under aseptic conditions as described by Driban et al. ${ }^{19}$ In both groups, arthrocentesis through the superolateral patella portal was performed using a $20 \mathrm{G} \times 32 \mathrm{~mm}$ sterile needle after local subcutaneous anesthesia with $2 \mathrm{~mL}$ at $1 \%$ lidocaine hydrochloride. Approximately 2 to $10 \mathrm{~mL}$ of SF was collected. Aliquots were centrifuged for 15 minutes and supernatants were kept frozen and stored at $-80{ }^{\circ} \mathrm{C}$. For both groups, simultaneously, venous blood sample was taken by sterile venipuncture. The separated serum was kept frozen at $-80{ }^{\circ} \mathrm{C}$ for analysis.

To estimate COMP levels in serum and synovial fluid samples, a human enzyme-linked immunosorbent assay was used, following manufacturer's instructions (Cloud-Clone Corp, SEB197Hu, Wuhan, China).

To explore influence of daytime variation in COMP levels, the samples were collected during medical consultation schedules: A) from morning to late mid-day ( $8 \mathrm{am}$ to $12 \mathrm{pm}$ ), and B) late day (after $13 \mathrm{pm}$ to $18 \mathrm{pm}$ ). SF samples were collected by an orthopedist. Sample processing was performed twice; SF samples were examined to exclude septic, metabolic or rheumatoid diseases.

\section{Statistical analysis}

All statistical analyses were performed using IBM SPSS version 22.0 software (IBM Corp., Armonk, NY, USA). Comparative analyses between groups were carried out using nonparametric tests. Mann-Whitney $U$ test was used to compare medians between groups while Kruskal-Wallis test was used to compare COMP levels among severity grades of disease. In addition, Spearman coefficients were estimated to examine the correlation between COMP values with daytime variation, age, and KellgrenLawrence grades of severity. Finally, $p<0.05$ was regarded as indicative of a significant difference.

\section{RESULTS}

The clinical and demographic characteristics of participants of this study, along with their corresponding COMP levels, are depicted in Table 2. Total SF COMP levels were considerably higher than total serum levels $(676.6 \mathrm{ng} / \mathrm{mL}$ vs $257.5 \mathrm{ng} / \mathrm{mL}$ ) (Table 3). Additionally, both COMP levels in SF and serum were higher in patients than in controls (SF, $p=0.033$ and serum $p=0.035$ ). Interestingly, COMP levels in SF were significantly higher only in female patients $(p=0.007)$ (Table 3). 
Table 2. Clinical characteristics of primary knee osteoarthritis patients and healthy individuals

\begin{tabular}{|c|c|c|c|c|c|c|c|c|c|c|}
\hline & & & Primary & $\mathrm{KOA}(\mathrm{n}=1$ & & & Con & ol group & $n=105)$ & \\
\hline & Mild & Moderate & Severe & & & & & & & \\
\hline & $\%$ & $\%$ & $\%$ & Median & Range & Min-Max & Median & Range & Min-Max & $p$ \\
\hline Age (year) & & & & 66 & $42-87$ & & 50 & $30-75$ & & $0.0001^{* *} \dagger$ \\
\hline $\begin{array}{l}\text { Sex } \\
\quad \text { Male } \\
\text { Female }\end{array}$ & $\begin{array}{l}22.7 \\
13.8\end{array}$ & $\begin{array}{l}40.9 \\
55.0\end{array}$ & $\begin{array}{l}36.4 \\
31.2\end{array}$ & $\begin{array}{l}62 \\
67\end{array}$ & $\begin{array}{l}49-85 \\
42-87\end{array}$ & & $\begin{array}{l}50 \\
50\end{array}$ & $\begin{array}{l}40-75 \\
30-71\end{array}$ & & $\begin{array}{l}0.259 \neq \\
0.0001^{* * *} \dagger \\
0.0001^{* * *} \dagger\end{array}$ \\
\hline $\begin{array}{c}\mathrm{BMI} \mathrm{kg} / \mathrm{m}^{2} \\
\text { Male } \\
\text { Female }\end{array}$ & & & & $\begin{array}{c}27.7 \\
28.97 \\
27.59\end{array}$ & $18.5-45.7$ & $\begin{array}{l}18.5-45.7 \\
21.1-45.5\end{array}$ & $\begin{array}{l}27.3 \\
27.7 \\
26.5\end{array}$ & & $\begin{array}{c}19-47.3 \\
19-47.3 \\
19.5-41.1\end{array}$ & $\begin{array}{l}0.233 \dagger \\
0.181 \dagger \\
0.631 \dagger\end{array}$ \\
\hline
\end{tabular}

Regarding daytime variation, COMP levels were increased when sampling after $12 \mathrm{pm}$, but only KOA SF COMP levels were statistically significant when compared to controls (Table S1). Also, SF COMP levels showed a gradual increase with severity of KOA $(p=0.012)$ (Table 4). In contrast, for serum COMP levels, this pattern was not observed. In addition, a correlation between SF and serum COMP was found. Finally, age, severity of disease, and diurnal variation were positively correlated with SF COMP levels (Table 5).

\section{DISCUSSION}

The employment of biomarkers related to cartilage degradation may be useful in the diagnosis of OA. In a previous study performed by Sudhir Singh et al., ${ }^{20}$ serum COMP levels were higher in patients when compared to controls. Thus, this group have suggested that COMP may be used as a potential biomarker to diagnose OA patients, suggesting also the possibility to establish cutoff serum COMP levels to discriminate between the grades of severity of disease. ${ }^{2}$

Our study aimed to measure and compare serum and SF COMP levels in patients with primary KOA and healthy individuals to find out whether COMP could have a potential role for diagnosis in KOA patients. Moreover, we aimed to compare SF and serum levels of this biomarker considering age, sex, severity of disease and diurnal variation. In addition, we aimed to correlate SF and serum COMP levels with diurnal variation, particularly within primary KOA patients.

Results of this study showed significant differences when comparing primary KOA vs healthy individuals, in which COMP levels in SF were higher than serum in both groups of study. Similar results were found by El-Arman et al., ${ }^{21}$ Gheita et al., ${ }^{22}$ and Andereya et al., ${ }^{23}$ suggesting that COMP is produced in the joint and associated

Table 3. Comparative analysis of synovial fluid and serum cartilage oligomeric matrix protein levels by sex

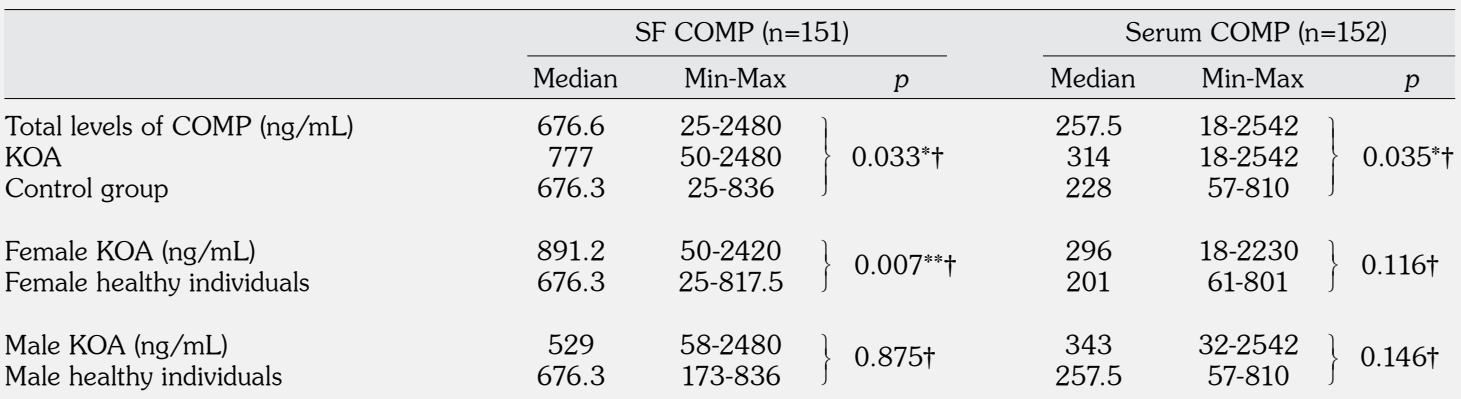

SF: Synovial fluid; COMP: Cartilage oligomeric matrix protein; Min: Minimum; Max: Maximum; KOA: Knee osteoarthritis; † Mann Whitney U test; * Significant if $p<0.05 ;{ }^{* *}$ Significant if $p<0.01$. 


\begin{tabular}{|c|c|c|c|c|}
\hline & \multicolumn{2}{|c|}{ SF COMP $(n=151)$} & \multicolumn{2}{|c|}{ Serum COMP $(n=152)$} \\
\hline & Median & Min-Max & Median & Min-Max \\
\hline $\begin{array}{l}\text { Daytime sampling A ( } 8 \text { to } 12 \mathrm{pm}) \\
\text { Daytime sampling B (13 to } 18 \mathrm{pm}) \\
\text { p-value }\end{array}$ & $\begin{array}{c}676.3 \\
891 \\
0\end{array}$ & $\begin{array}{l}25-2394 \\
109-2480 \\
8 \neq^{*}\end{array}$ & $\begin{array}{l}240 \\
305 \\
0\end{array}$ & $\begin{array}{l}18-2230 \\
61-2542 \\
3 \neq\end{array}$ \\
\hline $\begin{array}{l}\text { Daytime sampling A ( } 8 \text { to } 12 \mathrm{pm}) \mathrm{KOA} \\
\text { Daytime sampling A ( } 8 \text { to } 12 \mathrm{pm} \text { ) control } \\
\text { p-value }\end{array}$ & $\begin{array}{r}527.0 \\
676.3 \\
0\end{array}$ & $\begin{array}{l}50-2394 \\
25-836 \\
0 \neq\end{array}$ & $\begin{array}{r}270.0 \\
235.0 \\
0\end{array}$ & $\begin{array}{l}18-2230 \\
57-810 \\
8 \neq\end{array}$ \\
\hline $\begin{array}{l}\text { Daytime sampling B ( } 13 \text { to } 18 \mathrm{pm}) \mathrm{KOA} \\
\text { Daytime sampling B ( } 13 \text { to } 18 \mathrm{pm} \text { ) control } \\
\text { p-value }\end{array}$ & $\begin{array}{r}892.5 \\
406.5 \\
0\end{array}$ & $\begin{array}{l}109-2480 \\
173-817.2 \\
1 \neq^{*}\end{array}$ & $\begin{array}{r}325.5 \\
211.5 \\
0\end{array}$ & $\begin{array}{l}61-2542 \\
85-374) \\
37 \neq\end{array}$ \\
\hline $\begin{array}{l}\text { Daytime sampling A ( } 8 \text { to } 12 \mathrm{pm}) \mathrm{KOA} \\
\text { Daytime sampling B (13 to } 18 \mathrm{pm}) \mathrm{KOA} \\
\text { p-value }\end{array}$ & $\begin{array}{c}527 \\
892.5 \\
\end{array}$ & $\begin{array}{c}50-2394 \\
109-2480 \\
8 \neq^{*}\end{array}$ & $\begin{array}{c}270 \\
325.5 \\
0\end{array}$ & $\begin{array}{l}18-2230 \\
61-2542 \\
34 \neq\end{array}$ \\
\hline $\begin{array}{l}\text { Daytime sampling A ( } 8 \text { to } 12 \mathrm{pm} \text { ) control } \\
\text { Daytime sampling B ( } 13 \text { to } 18 \mathrm{pm} \text { ) control } \\
\text { p-value }\end{array}$ & $\begin{array}{c}400.50 .128 \ddagger \\
0\end{array}$ & $\begin{array}{l}25-836 \\
173-817.2 \\
8 \neq\end{array}$ & $\begin{array}{r}235.0 \\
211.5 \\
0\end{array}$ & $\begin{array}{l}57-810 \\
85-374 \\
36 \neq\end{array}$ \\
\hline
\end{tabular}

with cartilage turnover. The renal clearance of serum COMP is another possible explanation to those findings.

Some studies have concluded that serum COMP levels vary between sexes and among different ethnicities. ${ }^{6,24}$ Indeed, COMP levels may vary in biologic fluids, due to several factors. Therefore, for a correct interpretation of changes in levels of molecular biomarkers, it is important to evaluate other factors that may influence such variation. Our results have shown a significant difference when comparing SF COMP levels among patients and controls, mainly in the female group. A possible explanation to these findings is that female patients were significantly older than female controls and affected males, along with a higher sample size in females compared to males.
Moreover, age was correlated to SF and serum COMP levels.

In addition, Vilim et al. ${ }^{25}$ found that serum COMP levels were correlated with age, synovitis, and an interaction of synovitis and OA severity. In our study, SF COMP was positively correlated with age, daytime sampling, and severity of disease, while serum COMP was positively correlated with age and negatively with severity of disease.

Daytime variation is also an important issue to be considered as the influence of associated activity may modify levels of biomarkers. It has been reported that serum COMP levels remain constant during normal daytime activities (between 8 am and $9 \mathrm{pm}$ ) and it is not necessary

Table 4. Comparison between synovial fluid, serum levels of cartilage oligomeric matrix protein, and different Kellgren-Lawrence grades

\begin{tabular}{|c|c|c|c|c|c|c|c|}
\hline & \multicolumn{2}{|c|}{ Mild $(n=14)$} & \multicolumn{2}{|c|}{ Moderate $(n=50)$} & \multicolumn{2}{|c|}{ Severe $(n=41)$} & \multirow[b]{2}{*}{$p$} \\
\hline & Median & Min-Max & Median & Min-Max & Median & Min-Max & \\
\hline \multirow[t]{3}{*}{ Synovial fluid COMP (ng/mL) } & 325.5 & $50-1549$ & 765.5 & $85-2420$ & 891.5 & $165-2480$ & $0.012 * \dagger$ \\
\hline & \multicolumn{2}{|c|}{ Mild $(n=13)$} & \multicolumn{2}{|c|}{ Moderate $(n=41)$} & \multicolumn{2}{|c|}{ Severe $(n=21)$} & \\
\hline & Median & Min-Max & Median & Min-Max & Median & Min-Max & $p$ \\
\hline Serum COMP (ng/mL) & 296 & $32-2542$ & 445 & $65-2230$ & 195 & $18-1581$ & $0.121 \dagger$ \\
\hline
\end{tabular}


Table 5. Correlation analysis of synovial fluid and serum cartilage oligomeric matrix protein levels

\begin{tabular}{|c|c|c|c|c|}
\hline Parameter & $\operatorname{SF}$ COMP $(\mathrm{ng} / \mathrm{mL})$ & $p$ & Serum COMP (ng/mL) & $p$ \\
\hline Daytime variation & 0.179 & $0.014^{*} \dagger$ & 0.041 & 0.310 \\
\hline Daytime variation (KOA) & 0.230 & $0.009^{* *} \dagger$ & 0.032 & 0.393 \\
\hline Daytime variation (controls) & -0.227 & 0.065 & -0.080 & 0.245 \\
\hline Age & 0.266 & $0.001^{* *} \dagger$ & 0.179 & $0.013^{*} \dagger$ \\
\hline $\mathrm{K} / \mathrm{L}$ grades & 0.223 & $0.011^{*} \dagger$ & -0.200 & $0.043^{*} \dagger$ \\
\hline Serum COMP (ng/mL) & 0.212 & $0.035^{*} \dagger$ & & \\
\hline Serum COMP $(\mathrm{ng} / \mathrm{mL}) \mathrm{KOA}$ & 0.232 & $0.043^{*} \dagger$ & & \\
\hline
\end{tabular}

to standardize the time of serum sampling. ${ }^{26}$ Andersson et al. ${ }^{27}$ reported that levels of serum COMP may be affected by exercise, especially during the first 30 minutes. Therefore, serum samples for COMP analysis should be drawn after at least 30 minutes of rest. However, the authors concluded that changes in serum levels of COMP are minor and do not compromise the utility of serum COMP as a biomarker. Although authors have demonstrated daytime variation in some related biomarkers in serum and urine, ${ }^{28}$ we did not find a modification in serum COMP levels. However, the importance of diurnal variation of COMP levels in SF has not been fully addressed in the literature. In our study, only SF showed a significant increase in COMP levels after $12 \mathrm{pm}$ when comparing groups (mainly in the KOA group), highlighting the importance to consider daytime variation of COMP levels in this biologic fluid to avoid false diagnosis.

Moreover, levels of COMP in SF were increased according to the severity of disease. Also, we found a correlation in SF and diurnal variation (particularly in the KOA group). This modification in SF levels of COMP was possibly due to an increase of activities after $12 \mathrm{pm}$.

To our knowledge, this is the first study in a Mexican population that compares and correlates SF and serum COMP levels with other important variables such as age, sex, severity of disease, and daytime sampling. We do not underestimate the value of serum sampling. Conversely, we consider that if possible, both biologic fluids should be considered for analysis of biomarkers, including COMP.

Although small size and low correlation indexes may be limitations of this study, we tried to overcome these by recruiting and sampling patients and controls under same conditions and diagnostic criteria. These results may suggest a potential relationship between COMP levels and primary KOA. However, we cannot strongly ensure that COMP is a totally reliable tool for diagnosis of $\mathrm{KOA}$ due to the variable nature of serum and SF COMP levels. In addition, an important step in the validation process for $\mathrm{OA}$ biomarkers is the knowledge of the variations in their levels in different biologic fluids under different circumstances to contribute to diagnosis, prognosis, preventive medicine, and new drug development for OA. Whenever possible, serum, urine, and SF should be considered for analysis of biomarkers in the study of OA. We believe that a multicentric study with a much larger sample size will be helpful to increase the certainty of these findings.

\section{Acknowledgments}

We would like to thank to administrative personnel of the Faculty of Medicine, Torreon, Mexico, for their invaluable logistical and administrative support. This study was funded by the Faculty of Medicine, Torreon, Universidad Autonoma de Coahuila, Mexico (P/PROFOCIE-2014-05MSIJ0010R-12 to RDA) and Instituto de Ciencia y Medicina Genomica, Torreon, Mexico.

\section{Declaration of conflicting interests}

The authors declared no conflicts of interest with respect to the authorship and/or publication of this article.

\section{Funding}

This study was funded by the Faculty of Medicine Torreon, Autonomous University of Coahuila, Mexico (P/PROFOCIE-2014-05MSIJ0010R-12 to RDA) and Genomic Medicine Institute, Torreon, Mexico. 


\section{REFERENCES}

1. Felson DT, Lawrence RC, Dieppe PA, Hirsch R, Helmick CG, Jordan JM, et al. Osteoarthritis: new insights. Part 1: the disease and its risk factors. Ann Intern Med 2000;133:635-46.

2. Losina E, Paltiel AD, Weinstein AM, Yelin E, Hunter DJ, Chen SP, et al. Lifetime medical costs of knee osteoarthritis management in the United States: impact of extending indications for total knee arthroplasty. Arthritis Care Res (Hoboken) 2015;67:203-15.

3. De Pavía-Mota E, Larios-González MG, BriceñoCortés G. Manejo de la osteoartrosis en Medicina Familiar y Ortopedia. Arch Med Fam 2005;3:93-8.

4. Palmieri B, Lodi D, Capone S. Osteoarthritis and degenerative joint disease: local treatment options update. Acta Biomed 2010;81:94-100.

5. Neustadt DH. Intra-articular injections for osteoarthritis of the knee. Cleve Clin J Med. 2006;73:897-8.

6. Bijlsma JW, Berenbaum F, Lafeber FP. Osteoarthritis: an update with relevance for clinical practice. Lancet 2011;377:2115-26.

7. Hedbom E, Antonsson P, Hjerpe A, Aeschlimann D, Paulsson M, Rosa-Pimentel E, et al. Cartilage matrix proteins. An acidic oligomeric protein (COMP) detected only in cartilage. J Biol Chem 1992;267:6132-6.

8. Tseng S, Reddi AH, Di Cesare PE. Cartilage Oligomeric Matrix Protein (COMP): A Biomarker of Arthritis. Biomark Insights 2009;4:33-44.

9. Halász K, Kassner A, Mörgelin M, Heinegård D. COMP acts as a catalyst in collagen fibrillogenesis. $\mathrm{J}$ Biol Chem 2007;282:31166-73.

10. Chen FH, Herndon ME, Patel N, Hecht JT, Tuan RS, Lawler J. Interaction of cartilage oligomeric matrix protein/thrombospondin 5 with aggrecan. J Biol Chem 2007;282:24591-8.

11. Garnero P, Piperno M, Gineyts E, Christgau S, Delmas PD, Vignon E. Cross sectional evaluation of biochemical markers of bone, cartilage, and synovial tissue metabolism in patients with knee osteoarthritis: relations with disease activity and joint damage. Ann Rheum Dis 2001;60:619-26.

12. Otterness IG, Niblack JF. Letter: Clotrimazole and rheumatoid arthritis. Lancet 1976;1:148.

13. Verma P, Dalal K. Serum cartilage oligomeric matrix protein (COMP) in knee osteoarthritis: a novel diagnostic and prognostic biomarker. J Orthop Res 2013;31:999-1006.

14. Sharif M, Saxne T, Shepstone L, Kirwan JR, Elson CJ, Heinegård D, et al. Relationship between serum cartilage oligomeric matrix protein levels and disease progression in osteoarthritis of the knee joint. $\mathrm{Br} \mathrm{J}$ Rheumatol 1995;34:306-10.

15. Felson DT. The current and future status of biomarkers in osteoarthritis. J Rheumatol 2014;41:834-6.

16. Saxne T, Heinegård D. Cartilage oligomeric matrix protein: a novel marker of cartilage turnover detectable in synovial fluid and blood. Br J Rheumatol
1992;31:583-91

17. Neidhart M, Hauser N, Paulsson M, DiCesare PE, Michel BA, Häuselmann HJ. Small fragments of cartilage oligomeric matrix protein in synovial fluid and serum as markers for cartilage degradation. $\mathrm{Br} \mathrm{J}$ Rheumatol 1997;36:1151-60.

18. Åhrman E, Lorenzo P, Holmgren K, Grodzinsky AJ, Dahlberg LE, Saxne T, et al. Novel cartilage oligomeric matrix protein (COMP) neoepitopes identified in synovial fluids from patients with joint diseases using affinity chromatography and mass spectrometry. J Biol Chem 2014;289:20908-16.

19. Driban JB, Cattano N, Balasubramanian E, Sitler MR, Amin M, Glutting J, et al. Saline-assisted aspirations for collecting synovial fluid from noneffused knees: technique and validation. J Sport Rehabil 2014;9.

20. Singh S, Shahi U, Kumar D, Shahi NT. Serum Cartilage Oligomeric Matrix Protein: Tool for early diagnosis and grading of severity of primary knee osteoarthritis. Int J Osteol Orthop 2014;1:1-7.

21. El-Arman MM, El-Fayoumi G, El-Shal E, El-Boghdady I, El-Ghaweet A. Aggrecan and cartilage oligomeric matrix protein in serum and synovial fluid of patients with knee osteoarthritis. HSS J 2010;6:171-6.

22. Gheita TA, El-Awar AH, El-Ansary MM, Raslan HM, El-Defrawy AO. Cartilage oligomeric matrix protein (COMP) levels in serum and synovial fluid in osteoarthritis (OA) patients: Correlation with clinical, radiological and laboratory parameters. Osteoarthritis Cartilage 2015;23:A85.

23. Andereya S, Streich N, Schmidt-Rohlfing B, Mumme T, Müller-Rath R, Schneider U. Comparison of modern marker proteins in serum and synovial fluid in patients with advanced osteoarthrosis and rheumatoid arthritis. Rheumatol Int 2006;26:432-8.

24. Jordan JM, Luta G, Stabler T, Renner JB, Dragomir $A D$, Vilim V, et al. Ethnic and sex differences in serum levels of cartilage oligomeric matrix protein: the Johnston County Osteoarthritis Project. Arthritis Rheum 2003;48:675-81.

25. Vilím V, Vytásek R, Olejárová $M$, Machácek $S$, Gatterová J, Procházka B, et al. Serum cartilage oligomeric matrix protein reflects the presence of clinically diagnosed synovitis in patients with knee osteoarthritis. Osteoarthritis Cartilage 2001;9:612-8.

26. Andersson ML, Petersson IF, Karlsson KE, Jonsson EN, Månsson B, Heinegård D, et al. Diurnal variation in serum levels of cartilage oligomeric matrix protein in patients with knee osteoarthritis or rheumatoid arthritis. Ann Rheum Dis 2006;65:1490-4.

27. Andersson ML, Thorstensson CA, Roos EM, Petersson IF, Heinegård D, Saxne T. Serum levels of cartilage oligomeric matrix protein (COMP) increase temporarily after physical exercise in patients with knee osteoarthritis. BMC Musculoskelet Disord 2006;7:98

28. Kong SY, Stabler TV, Criscione LG, Elliott AL, Jordan JM, Kraus VB. Diurnal variation of serum and 
urine biomarkers in patients with radiographic knee osteoarthritis. Arthritis Rheum 2006;54:2496-504.

29. Lohmander LS, Saxne T, Heinegård DK. Release of cartilage oligomeric matrix protein (COMP) into joint fluid after knee injury and in osteoarthritis. Ann Rheum Dis 1994;53:8-13.

30. Petersson IF, Sandquist L, Svensson B, Saxne T.
Cartilage markers in synovial fluid in symptomatic knee osteoarthritis. Ann Rheum Dis 1997;56:64-7.

31. Kühne SA, Neidhart M, Everson MP, Häntzschel H, Fine PR, Gay S, et al. Persistent high serum levels of cartilage oligomeric matrix protein in a subgroup of patients with traumatic knee injury. Rheumatol Int 1998;18:21-5. 